\author{
І.А. Зупанець' , О.А. Голубовська², А.В. Шкурба², С.К. Шебеко', А.С. Шаламай' \\ ${ }^{1}$ Національний фармацевтичний університет, Харків \\ ${ }^{2}$ Національний медичний університет імені О.О. Богомольця, Київ

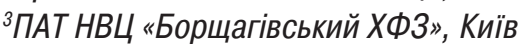

\title{
Перспективи вивчення застосування препаратів кверцетину в лікуванні COVID-19
}

У статті наведено етіопатогенетичне обґрунтування щодо доцільності вивчення застосування препаратів кверцетину для профілактики та лікування хворих на COVID-19. На підгрунті даних наукової літератури проведено аналіз особливостей фармакодинаміки кверцетину, які зумовлюють всебічний вплив на перебіг цієї патології, а також супутніх патологічних станів, що виникають внаслідок ускладнень або фармакотерапії загальноприйнятими хіміотерапевтичними та противірусними засобами. Особливу увагу приділено препаратам кверцетину вітчизняного виробництва - Квертин та Корвітин ${ }^{\circledR}$, що мають високотехнологічні лікарські форми, добре вивчені фармакокінетичні властивості водночас із високою безпекою застосування та хорошою переносимістю.

Ключові слова: кверцетин, Квертин, Корвітин ${ }^{\circledR}$, COVID-19, етіопатогенетичне обґрунтування.

Коронавірусна хвороба 2019 (COVID-19), збудником якої є вірус SARS-CoV-2, - найважливіша медико-соціальна проблема світового масштабу, що набула статусу пандемії. Ця патологія швидко поширюється у світі, спричиняючи такі ускладнення, як вірусна пневмонія, тяжкий гострий респіраторний синдром, сепсис, та внаслідокцього може завершуватися летальним кінцем (Liang T. (Ed.), 2020).

Захворювання, які спричинюють чотири людські коронавіруси, у людській популяції циркулюють тривалий час у вигляді гострих респіраторних вірусних інфекцій із нетяжким клінічним перебігом. Поява тяжкого гострого респіраторного синдрому (SARS) показала можливість потрапляння зоонозних коронавірусів, що відбулося наприкінці 2002 р. у Південному Китаї та призвело до $>8000$ випадків захворювань із загальним показником летальності близько 10\% (Peiris J.S. et al., 2003). Тривалість цього спалаху становила 8 міс, але скільки часу триватиме пандемія COVID-19невідомо.

До ситуації, що склалася, системи охорони здоров'я всіх країн світу виявилися не готовими. На сьогодні у клінічній практиці відсутні специфічні антивірусні засоби, що могли би застосовуватися з метою етіотропної терапії. Не створені вакцини. Тому підтримувальна допомога і неспецифічне лікування для зменшення вираженості симптомів COVID-19 поки що стали єдиними варіантами терапії при цьому захворюванні (Liang T. (Ed.), 2020).

У сучасних умовах лікування хворих на COVID-19 різної тяжкості відбувається із застосуванням значного арсеналу лікарських засобів з урахуванням особливостей розвитку хвороби, її перебігу в часі, пов'язаного зі швидкістю вірусного кліренсу. Підібраний великий арсенал хіміотерапевтичних засобів, незважаючи на відсутність чітко визначених протоколів, характеризується певним рівнем ефективності при неоднозначності процесу перебігу патології, включаючи катастрофічно тяжкі стани.

Відомо, що одночасно з підібраною методологією терапії понад 85\% хворих, інфікованих SARS-CoV-2, у період епідемії COVID-19 в Китаї отримували засоби традиційної китайської медицини (TKM) (Yang Y. et al., 2020). На сьогодні клінічні дані свідчать про сприятливий терапевтичний ефект ТКМ поряд із відомими хіміотерапевтичними засобами й антивірусними препаратами в динаміці лікування цих хворих.

Результати раніше проведених експериментальних досліджень дозволяють зрозуміти механізми, що лежать в основі терапевтичного ефекту ТКМ. Досліди щодо фармакотерапевтичних властивостей засобів ТКМ, дієтичних добавок рослинного походження й окремих виділених природних сполук підтвердили їх антивірусну, у тому числі антикоронавірусну активність (Yang Y. et al., 2020).
У цьому питанні великий науковий інтерес становляють флавоноїди, які у ряді досліджень проявили інгібувальну дію стосовно вірусних протеаз різних типів коронавірусів. У деяких експериментальних дослідженнях доведено інгібувальний вплив флавоноїдів, включаючи кверцетин, щодо 3С-подібної протеази (3CLpro) та папаїноподібної протеази (PLpro), які беруть участь у процесі протеолізу, i, отже, є важливими для інфікування та репродукції SARS-CoV-2 (Ling Y. et al., 2004; Lin C.W. et al., 2005; Gong S.J. et al., 2008; Nguyen T.T.H. et al., 2012; Jo S. et al., 2019; Seri J. et al., 2020). У зв'язку із широким спектром фармакодинаміки та низькою токсичністю препарати кверцетину давно привертають увагу дослідників. Найважливішими властивостями цих препаратів $€$ потужні антиоксидантні, імуномодулювальні та протизапальні властивості (Alrawaiq N., Abdullah A., 2014; Yao L. et al., 2016; Kumar R. et al., 2017).

Кверцетин насамперед є скавенджером вільних радикалів та має здатність активувати ферменти власного антиоксидантного захисту організму. Він чинить протизапальну дію, що зумовлено блокадою ліпооксигеназного шляху метаболізму арахідонової кислоти, зниженням синтезу лейкотрієнів, серотоніну та інших медіаторів запалення. Кверцетин підвищує активність фагоцитів, Т- і В-лімфоцитів та продукцію антитіл, знижуючи таким чином прояви вторинного імунодефіциту.

До того ж кверцетин $є$ одним із найпоширеніших та найдоступніших флавоноїдів, що накопичується у вигляді глікозидів багатьма лікарськими рослинами. У значних кількостях він міститься у плодах софори японської (Styphnolobium japonicum L.), корені солодки (Glycyrrhiza glabra L.), траві собачої кропиви (Leonurus cardiaca L.), квітках цмину піскового (Helichrysum arenarium L.), плодах чорної смородини, а також у винограді, яблуках, цибулі, перці тощо (Fortunato L.R., 2012). Відомо, що кверцетин $€$ також найпоширенішим флавоноїдом у харчовому раціоні, оскільки середньостатистична людина може отримувати з їжею до 100 мг кверцетину щодня (Bischoff S.C., 2008).

У дослідженнях in vitro кверцетин продемонстрував ефективність проти широкого спектра вірусів, зокрема щодо зворотної транскриптази вірусу імунодефіциту людини та інших ретровірусів, вірусу герпесу 1-го типу, вірусу поліомієліту I типу, вірусу парагрипу III типу, респіраторно-синцитіального вірусу, вірусу гепатиту С тощо. Так, результати експериментальних досліджень свідчать про активність кверцетину проти вірусу Зіка (Wong G. et al., 2017) та щодо ентеровірусу-71 (Yao C. et al., 2018).

Результати експериментальних досліджень також демонструють значний противірусний потенціал кверцетину проти SARSCoV-2 (Khaerunnisa S. et al., 2020; Smith M., Smith J.C., 2020). Встановлено, що кверцетин інгібує трипсиноподібні серинові 
протеїнази в мікромолярних концентраціях за рахунок зв'язування двома сусідніми фенольними гідроксильними групами з амінокислотними залишками каталітичного центру протеази, у тому числі з каталітично важливим залишком глутамінової кислоти, що $€$ характерною ознакою протеаз більшості вірусів.

Враховуючи приналежність SARS-CoV-2 до родини коронавірусів, що викликають різні захворювання дихальної системи, активність кверцетину була протестована щодо інших вірусів цієї родини. Так, встановлено, що кверцетин блокує надходження у клітину іншого коронавірусу, що спричиняє гостру респіраторну вірусну інфекцію (Yi L. et al., 2004). Результати дослідження T.T.H. Nguyen та співавторів (2012) також підтвердили противірусну активність кверцетину щодо SARS-CoV.

Вагомий інтерес становить захисний вплив кверцетину стосовно дихальної системи, особливо легеневої тканини. У дослідженні P. Kumar та співавторів (2005) кверцетин відновлював концентрацію багатьох антиоксидантів (каталази, глутатіондисмутази, супероксиддисмутази) у легенях лабораторних гризунів, заражених вірусом грипу А.

Застосування кверцетину в комплексі зі стандартною схемою лікування при гострій пневмонії значно покращувало результати терапії у дітей, знижуючи показники ендогенної інтоксикації та ліпопероксидації, а також підвищуючи активність антиоксидантної системи (Чорномидз І.Б., 2011). Також застосування кверцетину дозволяло знизити тривалість основних клінічних проявів пневмонії у дітей, зокрема ознак дихальної недостатності (Федорців О.Є., 2013). Доцільність застосування кверцетину показано і в пацієнтів із загостренням бронхіальної астми на фоні посиленої базисної та противірусної терапії (Дзюблик О.Я., 2013).

Інтерес до кверцетину як засобу профілактики та лікування COVID-19 при високій гостроті цієї проблеми на сьогодні знайшов свій відгук у багатьох фахівців наукового та лікувального профілю. Зокрема EVMS Medical Group рекомендує протокол ведення пацієнтів із COVID-19 (Marik P., 2020). Так, з метою зниження тяжкості захворювання в особливо вразливих осіб (віком >60 років), а також для пацієнтів із легкою симптоматикою, запропоновано для профілактики та лікування застосовувати комбінацію кверцетину та вітаміну C по 250-500 мг двічі на добу. Одночасне застосування кверцетину з вітаміном С викликає науково-практичний інтерес. Поєднання цих засобів може сприяти посиленню антивірусної дії кверцетину. Підставою для такого припущення є дослідження про те, що комбінація кверцетину 500 мг та вітаміну C 250 мг знижувала ризик пошкодження клітин, а також зменшувала вміст маркерів запалення (Askari G. et al., 2012).

Застосування кверцетину в лікуванні хворих на COVID-19 планується також у дослідженні канадських вчених M. Chretien та M. Mbikay, які мають досить великий досвід досліджень впливу кверцетину при гострих респіраторних інфекціях на тваринних моделях. При цьому за розробленим протоколом планується застосовувати дієтичну добавку кверцетину в дозі 500 мг протягом усього лікувального процесу за участю близько 1000 хворих. Управління із санітарного нагляду за якістю харчових продуктів та медикаментів США (Food and Drug Administration - FDA) затвердило кверцетин як безпечну для споживання людиною речовину, тому стає непотрібним тестування його безпеки на тваринах. Отже, кверцетин є доступною для лікування речовиною, яку можна швидко долучити до терапевтичного процесу. Передбачається, що застосування кверцетину в лікуванні хворих на COVID-19 матиме вагомі фармакоекономічні переваги, оскільки вартість досліджуваного лікування становитиме 2 дол. США на добу на одного пацієнта (Taylor-Vaisey N., 2020).

При достатньо глибокому вивченні антивірусної дії (рино- та ентеровіруси, вірус гепатиту C, грипу, Зіка та Менго) (Veckenstedt A. et al., 1987; Choi H.J. et al., 2009; Bachmetov L. et al., 2012 ; Ganesan S. et al., 2012; Johari J. et al., 2012; Lu N. et al., 2012; Wu W. et al., 2016; Wong G. et al., 2017; Zakaryan H. et al., 2017; Lalani S., Poh C.L., 2020) кверцетин володіє безперечно високим потенціалом антиоксидантної, антигіпоксичної, протизапальної, імуномодулювальної, кардіо-, нефро- та гепатопротекторної активності (Kelly G.S., 2011; Мойбенко A.A. (ред.), 2012; Shebeko S.K. et al., 2018).

Протягом тривалого часу в Україні проводилися дослідження з розроблення та фармакологічного вивчення препаратів кверце- тину для внутрішнього та парентерального застосування. На сьогодні на вітчизняному фармацевтичному ринку представлено два препарати виробництва ПАТ НВЦ «Борщагівський ХФЗ» - Квертин та Корвітин ${ }^{\circledast}$.

Препарат Квертин у формі жувальних таблеток має значні переваги над іншими відомими у світі кверцетинвмісними препаратами та дієтичними добавками за показниками фармакокінетики. Завдяки застосуванню особливого складу допоміжних речовин, що містить модифікатор розчинності пектин, вдалося значно покращити показники біодоступності кверцетину. У ході експериментального дослідження фармакокінетики препарату показано зростання біодоступності кверцетину в 10 разів порівняно з нативною субстанцією (Усенко В.Ф. та співавт., 2012).

3 огляду на ускладнення з боку серцево-судинної системи, спричинені впливом як самого коронавірусу, так і препаратів, які застосовують при лікуванні COVID-19 (Peiris J.S. et al., 2003; Liang T. (Ed.), 2020; Yang Y. et al., 2020), актуальними є дані про кардіопротекторний вплив кверцетину, отримані у ряді доклінічних досліджень.

у комплексному дослідженні ефективності кверцетину для запобігання гіпертрофії та ремоделювання міокарда різного генезу у щурів встановлено, що його застосування покращувало гемодинамічні параметри, зменшувало вираженість фібротичних змін у міокарді, що свідчить про його кардіопротекторну дію (Тумановська Л.В. та співавт., 2011). Експериментальна терапія кверцетином при ізопротеренол-індукованому ураженні міокарда сприяла зниженню масового коефіцієнта серця тварин та значною мірою запобігала розвитку як дифузних інтерстиціальних, так і осередкових фібротичних процесів у міокарді (Усенко В.Ф. та співавт., 2012). На моделі доксорубіцинової кардіоміопатії встановлено, що кверцетин стабілізує функціональні показники міокарда та зумовлює виражений антиоксидантний ефект, про що свідчить підвищення активності ферментів антиоксидантного захисту та зниження продуктів ліпопероксидації (Гур'янова В.Л. та співавт., 2014).

Враховуючи побічні ефекти, що виникають при лікуванні COVID-19 і пов'язані із застосуванням хлорохіну, антивірусних препаратів фавіпіравіру та ремдесивіру, які проявляють досить значну гепатотоксичність, застосування кверцетину доцільне з урахуванням його гепатопротекторної дії, що також доведено в експерименті (Лук'янчук В.Д., Войтенко А.Г., 2008).

До факторів ризику при захворюванні на COVID-19 також належить цукровий діабет і захворювання нирок. У дослідженні впливу кверцетину на метаболічний синдром у лабораторних щурів, індукований високофруктозною дієтою, встановлено, що відбувається гальмування розвитку інсулінорезистентності та інтолерантності до вуглеводів (Gorbenko N.I. et al. , 2019). Нефропротекторна дія кверцетину підтверджена в експериментальних дослідженнях за умов розвитку уражень нирок різної етіології, де він проявив позитивний вплив на показники структурно-функціонального стану нирок, сприяв нормалізації видільної функції нирок та азотистого обміну й зумовлював антиоксидантну дію (Shebeko S.K. et al., 2018).

Дані нещодавніх досліджень свідчать також про нейротоксичний вплив SARS-CoV-2, який зокрема проявляється у вигляді респіраторного дистрес-синдрому внаслідок токсичного пошкодження стовбуру мозку, що призводить до розладу кардіореспіраторного центру (Liang T. (Ed.), 2020). Церебропротекторний вплив препаратів кверцетину доведено на моделі підгострої нелетальної ішемії мозку у лабораторних щурів, що проявлялося у нормалізації рухово-дослідницької активності, підвищенні фізичної витривалості та зниженні інтенсивності вільнорадикального окиснення у структурах мозкових тканин (Мамчур В.Й., Слесарчук В.Ю., 2008).

Препарат Квертин також має протизапальні властивості. На моделі гострого асептичного запалення у мишей, спричиненого різними флогогенами, він виявляв антиексудативний ефект різного ступеня залежно від використаної моделі та механізмів запальної реакції, що спричиняють їі розвиток (Усенко В.Ф., 2011).

В експериментальних та клінічних дослідженнях доведено високу безпеку препарату Квертин. Він проявив відсутність побічних ефектів та хорошу переносимість у здорових добровольців (Усенко В.Ф., 2012). Показник ЛД50 при внутрішньошлунковому 
введенні препарату у мишей перевищував 5000 мг/кг маси тіла, у щурів - 10000 мг/кг, що дозволило віднести кверцетин до групи практично нетоксичних речовин (Усенко В.Ф. та співавт., 2011).

Для препарату Корвітин ${ }^{\circledast}$, який становить ліофілізований порошок для ін'єкцій, притаманні всі фармакологічні ефекти Квертину, але при вищому рівні ефективності, що зумовлено стовідсотковою біодоступністю на тлі хорошої переносимості у пацієнтів (Мойбенко А.А. (ред.), 2012; Shebeko S.K. et al., 2018). Фармакокінетичні властивості препарату Корвітин ${ }^{\circledR}$ ретельно вивчено у клінічних дослідженнях, у ході яких доведено, що цей засіб за умови внутрішньовенного застосування дозволяє швидко створити надвисокі концентрації кверцетину та його біоактивного метаболіту ізорамнетину у крові пацієнтів, які утримуються протягом достатньо тривалого часу для цього шляху введення, оскільки $\mathrm{T}_{1 / 2}$ становить близько 7 год (таблиця) (Зупанец И.А. и соавт., 2011; Zupanets I.A. et al., 2019). Завдяки цим особливостям препарат Корвітин ${ }^{\circledast}$ має широкі можливості для застосування за необхідності терапії хворих у тяжкому та критичному стані.

Таблиця. Усереднені фармакокінетичні параметри препарату Корвітин за умов внутрішньовенного застосування у здорових волонтерів у дозі 500 мг

\begin{tabular}{|c|c|c|c|c|c|c|}
\hline $\begin{array}{c}\mathrm{C}_{\max } \\
\text { (нг/Мл) }\end{array}$ & $\begin{array}{c}T_{\max } \\
\text { (год) }\end{array}$ & $\begin{array}{c}\text { AUC }_{0-\mathrm{t}} \\
\text { (нг · год/ } \\
\text { мл) }\end{array}$ & $\begin{array}{c}\text { AUC }_{0-\infty} \\
\text { (нг · год/ } \\
\text { мл) }\end{array}$ & $\begin{array}{l}\operatorname{AUC}_{0-\infty} / \\
\operatorname{AUC}_{0-\mathrm{t}}(\%)\end{array}$ & $\begin{array}{c}K^{\mathrm{el}} \\
\left(\mathbf{4}^{-1}\right)\end{array}$ & $\begin{array}{c}T_{1 / 2} \\
\text { (год) }\end{array}$ \\
\hline 3870,9 & 0,25 & 4136,8 & 4595,9 & 90,87 & 5,23 & 6,92 \\
\hline
\end{tabular}

Багаторічні клінічні дослідження препарату Корвітин ${ }^{\circledast}$ при лікуванні гострого інфаркту міокарда дозволили визначити найбільш доцільні умови його ефективного клінічного застосування, наблизитися до розуміння механізмів фармакологічної дії та розробити стратегічні підходи до лікування основного захворювання і близьких за етіопатогенезом патологічних станів (Мойбенко А.А и соавт., 2003; Пархоменко А.Н., Кожухов С.Н., 2005).

Кардіопротекторна дія кверцетину проявляється багатьма позитивними ефектами, серед яких особливо значними є обмеження зони некрозу міокарда, запобігання його реперфузійному ураженню; а також антиаритмічна, антиішемічна, антитромботична дії, встановлені при лікуванні гострого коронарного синдрому, гострого інфаркту міокарда та гострої серцевої недостатності (Пархоменко А.Н., Кожухов С.Н., 2005; 2009; 2014; Мойбенко А.А. и соавт., 2008; Пархоменко А.Н., 2008; Пархоменко А.Н. и соавт., 2008). Встановлено також його захисний вплив на ендотелій судин, що має вагоме значення при COVID-19, оскільки при цій патології неминуче розвивається ендотеліальна дисфункція (Varga Z. et al., 2020).

На сьогодні основними показаннями до застосування препарату Корвітин ${ }^{\circledR} €$ гостре порушення коронарного кровообігу, інфаркт міокарда, серцева недостатність, порушення церебральної гемодинаміки (Державний реєстр лікарських засобів, 2018). Окрім того, кверцетин є перспективним засобом щодо вивчення можливостей оптимізації медикаментозної терапії при нирковій патології. У ході експериментальних досліджень доведено його нефропротекторну та гіпоазотемічну дію при гострій та хронічній нирковій недостатності, а також хронічному гломерулонефриті (Зупанець І.А. та співавт., 2009а; в; Харченко Д.С. та співавт., 2009). За токсикологічними характеристиками препарати кверцетину практично не токсичні: експериментально визначений показник ЛД50 перевищує 5000 мг/кг при внутрішньоочеревинному введенні у щурів (Зупанець І.А. та співавт., 2009б).

Це зумовлює доцільність вивчення ефективності застосування препаратів кверцетину у хворих на COVID-19 для лікування у разі ускладнень з боку серцево-судинної, центральної нервової та інших систем та органів, що набуває особливої актуальності у хворих груп ризику, що характеризуються поліморбідністю.

Таким чином, препарати кверцетину мають великий досвід застосування у клінічній практиці та добре вивчений профіль безпеки, що зумовлює перспективу для вивчення їхньої ефективності щодо профілактики та супутньої терапії хворих на COVID-19. Доцільним є проведення клінічних випробувань Квертину з метою обґрунтування його застосування для профілактики та лікування при легких формах COVID-19 у пацієнтів, які не належать до груп ризику, та медичного персоналу, а препарату Корвітин ${ }^{\circledR}-$ при лікуванні COVID-19 середнього і тяжкого ступеня з ускладненнями насамперед з боку серцево-судинної та центральної нервової систем.

\section{Список використаної літератури}

Гур'янова В.Л., Кузьменко М.О., Тумановська Л.В. та ін. (2014) Молекулярно-генетичні аспекти розвитку фіброзу при ремоделюванні серця внаслідок адренергічного пошкодження міокарда. Вісн. морфол., 20(2): 314-318.

Державний реєстр лікарських засобів (2018) Інструкція для медичного застосування препарату Корвітин ${ }^{\circledast}$ (http://www.drlz.com.ua/ibp/ddsite.nsf/all/shlist?open document\&query=\%CA\%EE\%F0\%E2\%B3\%F2\%E8\%ED).

Дзюблик О.Я., Стежка В.А., Недлінська Н.М. та ін. (2013) Етіопатогенетичні аспекти лікування пацієнтів із вірус-індукованим загостренням бронхіальної астми. Астма та алергія, 2: 12-17.

Зупанец И.А., Подпружников Ю.В., Шаламай А.С., Безуглая Н.П. (2011) Изучение фармакокинетики лекарственного препарата «Корвитин ${ }^{\circledR}$. Укр. мед. альманах, 14(6): 81-83.

Зупанець І.А., Шебеко С.К., Харченко Д.С. (2009а) Дослідження впливу парентеральної форми кверцетину на перебіг гострої ниркової недостатності у щурів. Мед. хімія, 1(11): 98-102.

Зупанець І.А., Шебеко С.К., Харченко Д.С. (2009б) Дослідження гострої токсичності та середньоефективних доз кверцетину при парентеральному введенні в умовах розвитку ниркової недостатності у щурів. Фармакол. лік. токсикол., 1(8): $28-33$

Зупанець І.А., Шебеко С.К., Харченко Д.С. (2009в) Експериментальне вивчення фармакологічних властивостей парентеральної форми кверцетину в умовах розвитку хронічної ниркової недостатності. Вісн. фармац., 2(58): 75-78.

Лук'янчук В.Д., Войтенко А.Г. (2008) Кінетика вільнорадикальних реакцій у щурів з медикаментозним гепатитом при застосуванні таблеток «Кверцетин». Фармакологія та лікарська токсикологія, 1-3: 52-57.

Мамчур В.Й., Слесарчук В.Ю. (2008) Захисна дія препаратів кверцетину за умов моделювання гострого іммобілізаційного стресу. Фармакол. лік. токсикол., 1-3: 38-43.

Мойбенко А.А. (ред.) (2012) Биофлавоноиды как органопротекторы (кверцетин, корвитин, квертин). Наукова думка, Київ, 274 с

Мойбенко А.А., Досенко В.Е., Пархоменко А.Н. (2008) Эндогенные механизмы кардиопротекции как основа патогенетической терапии заболеваний сердца. Наукова думка, Київ, 518 с.

Мойбенко А.А., Пархоменко А.Н., Кожухов С.Н. (2003) Эффективность водорастворимой формы кверцетина (корвитина) при лечении острого коронарного синдрома с элевацией сегмента ST. Журн. АМН України, 9(2): 361-370.

Пархоменко А.Н. (2008) Метаболическая терапия, или кардиопротекция при ишемической болезни сердца: итоги и перспективы. Укр. мед. часопис, 4(66): $15-19$.

Пархоменко А.Н., Кожухов С.Н. (2005) Эффективность внутривенной формы блокатора 5-липоксигеназы кверцетина убольных с инфарктом миокарда и синдромом острой сердечной недостаточности: возможная связь с коррекцией метаболизма оксида азота. Укр. мед. часопис, 5: 45-51.

Пархоменко А.Н., Кожухов С.Н. (2009) Проспективный регистр острой декомпенсированной сердечной недостаточности: опыт одного центра. Укр. мед. часопис, 4(72): 10-13.

Пархоменко А.Н., Кожухов С.Н. (2014) Результаты открытого рандомизированного исследования по изучению переносимости и эффективности препарата Корвитин ${ }^{\circledast}$ у пациентов с застойной сердечной недостаточностью и систолической дисфункцией левого желудочка. Укр. мед. часопис, 4(102): 71-76.

Пархоменко А.Н., Кожухов С.Н., Мойбенко А.А., Гавриленко Т.И. (2008) Блокатор 5-липоксигеназы Корвитин: влияние на маркеры воспаления иэндотелиәльной дисфункции у больных с острым инфарктом миокарда. Рац. фармакотер., 2/1: 85-88.

Тумановська Л.В., Мойбенко О.О., Павлюченко В.Б. та ін. (2011) Спосіб попередження ремоделювання міокарда. Патент України № 60950 (http://uapatents. com/5-60950-sposib-poperedzhennya-remodelyuvannya-miokarda.html).

Усенко В.Ф. (2011) Вплив препарату «Квертин» на альтеративне та проліферативне запалення в експерименті. Клін. фармац., 15(3): 36-38.

Усенко В.Ф. (2012) Клініко-фармакологічне обґрунтування застосування препарату «Квертин» в терапії остеоартрозів. Автореф. дис. ... канд. мед. наук. Одеса, $20 \mathrm{c}$

Усенко В.Ф., Зупанець І.А., Безугла Н.П. та ін. (2011) Дослідження переносимості та безпеки нового оригінального препарату «Квертин». Укр. мед. альманах, 14(4): 208-209.

Усенко В.Ф., Зупанець І.А., Тарасенко О.О., Шебеко С.К. (2012) Експериментальне дослідження фармакокінетичних властивостей кверцетинупри пероральному застосуванні з модифікаторами розчинності. Мед. хімія, 14(1): 91-95.

Федорців О.є. (2013) Клінічна ефективність використання кверцетину у комплексному лікуванні дітей, хворих на позалікарняну пневмонію. Акт. пит. педіатр. акушер. гінекол., 2: 7-9.

Харченко Д.С., Зупанец И.А., Шебеко С.К. (2009) Изучение влияния кверцетина при парентеральном введении на биохимические показатели крыс с почечной недостаточностью на фоне хронического гломерулонефрита. Фармаком, 2: 117-121.

Чорномидз І.Б. (2011) Клініко-патогенетичне обґрунтування застосування кверцетину у комплексному лікуванні дітей із гострою позалікарняною пневмонією. Вісн. наук. досл., 1: 34-36. 
Alrawaiq N., Abdullah A. (2014) A review of flavonoid quercetin: metabolism, bioactivity and antioxidant properties. Int. J. Pharm. Tech. Res., 6(3): 933-941.

Askari G., Ghiasvand R., Feizi A. et al. (2012) The effect of quercetin supplementation on selected markers of inflammation and oxidative stress. J. Res. Med. Sci. 6: 637-641

Bachmetov L., Gal-Tanamy M., Shapira A. et al. (2012) Suppression of hepatitis $\mathrm{C}$ virus by the flavonoid quercetin is mediated by inhibition of NS3 protease activity. J. Viral. Hepat., 19: 81-88.

Bischoff S.C. (2008) Quercetin: potentials in the prevention and therapy of disease. Curr. Opin. Clin. Nutr. Metab. Care, 11(6): 733-740.

Choi H.J., Song J.H., Park K.S., Kwon D.H. (2009) Inhibitory effects of quercetin 3-rhamnoside on influenza A virus replication. Eur. J. Pharm. Sci., 37: 329-333.

Fortunato L.R. (2012) Quercetin: a flavonoid with the potential to treat asthma. Braz. J. Pharm. Sci., 48(4): 590-598.

Ganesan S., Faris A.N., Comstock A.T. et al. (2012) Quercetin inhibits rhinovirus replication in vitro and in vivo. Antiviral Res., 94: 258-271.

Gong S.J., Su X.J., Yu H.P. et al. (2008) A study on anti-SARS-CoV 3CL protein of flavonoids from litchi chinensis sonn core. Chinese Pharmacological. Bulletin., 24 $699-700$.

Gorbenko N.I., Borikov O.Yu., Ivanova O.V. et al. (2019) The effect of quercetin on oxidative stress markers and mitochondrial permeability transition in the heart of rats with type 2 diabetes. Ukr. Biochem. J., 91(5): 46-54.

Jo S., Kim H., Kim S. et al. (2019) Characteristics of flavonoids as potent MERS-CoV 3C-like protease inhibitors. Chem. Biol. Drug Des., 94(6): 2023-2030.

Johari J., Kianmehr A., Mustafa M. et al. (2012) Antiviral Activity of Baicalein and Quercetin against the Japanese Encephalitis Virus. Int. J. Mol. Sci., 13: 16785-16795

Kelly G.S. (2011) Quercetin. Monograph. Alt. Med. Rev., p. 172-194.

Khaerunnisa S., Kurniawan H., Awaluddin R., Suhartati S. (2020) Potential Inhibitor of COVID-19 Main Protease (Mpro) From Several Medicinal Plant Compounds by Molecular Docking Study. doi: 10.20944/preprints202003.0226.v1.

Kumar P., Khanna M., Srivastava V. et al. (2005) Effect of quercetin supplementation on lung antioxidants after experimental influenza virus infection. Exp. Lung Res., 31(5): 449-459.

Kumar R., Vijayalakshmi S., Nadanasabapathi S. (2017) Health Benefits of Quercetin. Def. Life Sci. J., 2(2): 142-151.

Lalani S., Poh C.L. (2020) Flavonoids as Antiviral Agents for Enterovirus A71(EVA71), 12: 184.

Liang T. (Ed.) (2020) Handbook of COVID-19. Prevention and Treatment. Zhejiang University School of Medicine, $60 \mathrm{p}$

Lin C.W., Tsai F.J., Tsai C.H. et al. (2005) Anti-SARS coronavirus 3C-like protease effects of Isatis indigotica root and plant-derived phenolic compounds. Antiviral Res., 68: 36-42.

Ling Y., Zhengquan L., Kehu Y. et al. (2004) Small molecules blocking the entry of severe acute respiratory syndrome coronavirus into host cells. J. Virol., 78: $11334-11339$.

Lu N., Khachatoorian R., French S.W. (2012) Quercetin: Bioflavonoids as part of interferon-free hepatitis C therapy? Expert Rev. Anti Infect., 10: 619-621.
Marik P. (2020) EVMS critical care COVID-19 management protocol (https://www. evms.edu/media/evms public/departments/internal_medicine/EVMS_Critical_Care_COVID-19 Protocol.pdf).

Nguyen T.T.H., Woo H.-J., Kang H.-K. et al. (2012) Flavonoid-mediated inhibition of SARS coronavirus 3C-like protease expressed in Pichia pastoris. Biotechnol. Lett., 34(5): 831-838.

Peiris J.S., Lai S.T., Poon L.L. et al. (2003) Coronavirus as a possible cause of severe acute respiratory syndrome. Lancet, 361: 1319-1325.

Seri J., Suwon K., Dong Hae Sh., Mi-Sun K. (2020) Inhibition of SARS-CoV 3CL protease by flavonoids. J. Enzyme Ingibit. Med. Chem., 35(1): 145-151.

Shebeko S.K., Zupanets I.A., Popov O.S. et al. (2018) Effects of quercetin and its combinations on health. In: R.R. Watson, R.V. Preedy, S. Zibadi (Eds.). Polyphenols: mechanisms of action in human health and disease: monograph. London, Academic Press, p. 373-394.

Smith M., Smith J.C. (2020) Repurposing therapeutics for COVID-19: supercomputer-based docking to the SARS-CoV-2 viral spike protein and viral spike protein-human ACE2 interface. ChemRxiv. doi: 10.26434/chemrxiv.11871402.

Taylor-Vaisey N. (2020) A made-in-Canada solution to the coronavirus outbreak? (https://www.macleans.ca/news/canada/a-made-in-canada-solution-to-the-coronavirusoutbreak/).

Varga Z., Flammer A.J., Steiger P. et al. (2020) Endothelial cell infection and endotheliitis in COVID-19. Lancet, 395(10234): 1417-1418. doi: 10.1016/S01406736(20)30937-5

Veckenstedt A., Güttner J., Béládi I. (1987) Synergistic action of quercetin and murine alpha/beta interferon in the treatment of Mengo virus infection in mice. Antiviral Res., 7(3): 169-178.

Wong G., He S., Siragam V. et al. (2017) Antiviral activity of quercetin-3- $\beta-0-$ D-glucoside against Zika virus infection. Virol. Sin., 32(6): 545-547. doi: 10.1007/ s12250-017-4057-9.

Wu W., Li R., Li X. et.al. (2016) Quercetin as an Antiviral Agent Inhibits Influenza A Virus (IAV) Entry. Viruses, 8(1): 6

Yang Y., Islam M.S., Wang J. et al. (2020) Traditional chinese medicine in the treatment of patients infected with 2019-new coronavirus (SARS-CoV-2): a review and perspective. Int. J. Biol. Sci., 16(10): 1708-1717.

Yao C., Xi C., Hu K. et al. (2018) Inhibition of enterovirus 71 replication and viral 3C protease by quercetin. Virol. J., 15(1): 116. doi: 10.1186/s12985-018-1023-6.

Yao L., Jiaying Y., Chunyan H. et al. (2016) Quercetin, inflammation and immunity. Nutrients, 167(8): 1-14.

Yi L., Li Z., Yuan K. et al. (2004) Small molecules blocking the entry of severe acute respiratory syndrome coronavirus into host cells. J. Virol., 78(20): $11334-11339$.

Zakaryan H., Arabyan E., 00 A., Zandi K. (2017) Flavonoids: promising natural compounds against viral infections. Arch. Virol., 162: 2539-2551.

Zupanets I.A., Pidpruzhnykov Y.V., Sabko V.E. et al. (2019) UPLC-MS/MS quantification of quercetin in plasma and urine following parenteral administration. Clin. Phytosci., Art. 5. ID 11.

\section{РЕФЕРАТИВНА ІНФОРМАЦІЯ}

\section{Методи приготування безпечної кави з огляду} на серцево-судинні захворювання

В умовах самоізоляції люди частіше вживають улюблені напої, в тому числі каву. Згідно з результатами першого дослідження проведеного з метою вивчення зв'язку між методами заварювання кави та ризиком виникнення серцевих нападів, вчені з норвезького Інституту громадської охорони здоров'я дійшли висновку, що фільтрований напій є найбільш безпечним. Результати дослідження опубліковані в «European Journal of Preventive Cardiology» - журналі Європейського товариства кардіологів (ESC).

Автор дослідження, професор з Університету Гетеборгу у Швеції, Даг Тель каже: «Наше дослідження надає переконлив докази щодо взаємозв'язку між методами заварювання кави, серцевими нападами і тривалістю життя. Нефільтрована кава містить речовини, які підвищують рівень холестерину у крові. Використання фільтра дозволяє вилучити їх, таким чином знизити вірогідність розвитку серцевих нападів і передчасної смерті». Д. Тель виявив ще 30 років тому, що вживання кави пов'язане із підвищеним вмістом загального холестерину та ліпопротеїнів низької щільності. Чашка нефільтрованої кави містить приблизно у 30 разів вищу концентрацію речовин, що підвищують вміст ліпідів, порівняно із фільтрованою кавою.

У 1985-2003 рр. до дослідження була включена репрезентативна вибірка норвезького населення: 508747 здорових чолові- ків та жінок віком від 20 до 79 років. Учасники пройшли анкетування щодо кількості та типу споживаної кави. Також було зібрано дані щодо змінних, які могли вплинути як на споживання кави, так і на хвороби серця, а саме: тютюнопаління, фізична активність, зріст, маса тіла, артеріальний тиск та рівень холестерину.

Учасники перебували під спостереженням близько 20 років. Загалом помер 46461 доброволець. 3 них 12621 помер від серцево-судинних захворювань, а 6202 випадки були спричинені інфарктом.

Загалом споживання кави не є небезпечною звичкою. Вживання фільтрованої кави безпечне, адже напій на 15\% знижує ризик смерті від будь-яких серцево-судинних захворювань. Фільтрований напій асоціюється зі зниженням ризику смерті серед чоловіків на $12 \%$, а серед жінок - на 20\%. Найнижча смертність зафіксована серед людей, які споживали від 1 до 4 чашок фільтрованої кави на день.

Проте професор Д. Тель зазначив, що нефільтрована кава не підвищує ризику смертності порівняно з повною відмовою від неї, за винятком чоловіків віком від 60 років.

Tverdal A., Selmer R., Cohen J. et al. (2020) Coffee consumption and mortality from cardiovascular diseases and total mortality: Does the brewing method matter? (https://journals.sagepub.com/doi/10.1177/2047487320914443).

Катерина Приходько-Дибська 